\title{
Microleakage in Bonded Amalgam Restorations Using Different Adhesive Materials
}

\author{
Maximiliano Sérgio CENCI ${ }^{1}$ \\ Evandro PIVA ${ }^{1}$ \\ Fernando POTRICH ${ }^{1}$ \\ Elenita FORMOLO ${ }^{1}$ \\ Flávio Fernando DEMARCO ${ }^{1}$ \\ John M. POWERS ${ }^{2}$ \\ ${ }^{1}$ Federal University of Pelotas, School of Dentistry, Pelotas, RS, Brazil \\ ${ }^{2}$ The University of Texas Dental Branch at Houston, Houston Biomaterials Research Center, Houston, TX, USA
}

\begin{abstract}
The aim of this study was to verify the ability of different adhesive materials to prevent microleakage in bonded amalgam restorations. Standard cavities were prepared in both buccal and lingual surfaces of 35 bovine incisors. The gingival wall was located in cementum/ dentin and the occlusal wall in enamel. Teeth $(n=35)$ were divided into 5 groups, according to material employed (one glass-ionomer cement, two resin cements, one adhesive system, and Copalex varnish as a control). Following restoration, the teeth were submitted to thermal cycling. The teeth were subsequently immersed in methylene blue dye and sectioned to allow assessment of microleakage. Nonparametric statistical analysis indicated that all materials demonstrated less leakage than the control group ( $<<0.01)$. No leakage was found using the resin-modified glass-ionomer cement, which was significantly different from the other adhesive materials $(\mathrm{p}<0.05)$. Leakage in enamel was lower than in cementum/dentin margins. It was concluded that bonded amalgam was an effective technique, since all materials prevented microleakage in enamel and cementum/dentin, when compared to the control group, except Panavia in cementum/dentin margins.
\end{abstract}

Key Words: bonded amalgam, microleakage, bovine teeth.

\section{INTRODUCTION}

Dental amalgam has been used successfully for more than 170 years as a restorative material. It has several advantages, such as easy manipulation and placement, good wear resistance, low technique sensitivity, acceptable life expectancy, and low cost (1). However, the material lacks adhesive properties, making undercuts necessary for mechanical retention.

In an attempt to reduce tooth undercuts, to prevent breakdown at the margins and decrease microleakage of amalgam restorations, adhesive materials have been used as liners under amalgam (2). Microleakage has been identified as a significant problem with amalgam because of interfacial gap formation and can result in tooth discoloration, pulp irritation and secondary caries (3).
Copal varnish liners have also been used in an attempt to reduce microleakage, however, they fail to maintain long-term sealing. Such findings are mainly due to the solubility of the material and dissolution of the underlying smear layer (4). Several studies have demonstrated better sealing using adhesive materials than Copal varnish under amalgam restorations. Different intermediate adhesive materials have been employed in a bonded technique, producing different sealing ability (3-5).

The purpose of this study was to compare the microleakage between conventional and bonded amalgam restorations, using different adhesive materials.

\section{METHODS AND MATERIALS}

Thirty-five, freshly extracted, bovine incisor teeth 
were selected and stored frozen until testing. The teeth were examined under magnification to ensure that they were free of fractures or structural defects. Before any procedure, teeth were cleaned, autoclaved and maintained in saline solution. Root apices were cut off with a \#1070 diamond bur, and pulp was removed.

Standardized Class V cavities were prepared on both buccal and lingual surfaces of each tooth, using a high-speed hand piece with air-water spray and a \# 250 carbide bur. The burs were replaced after 6 cavity preparations to ensure cutting ability. The preparations were oblong in shape ( $2 \times 2 \times 2 \mathrm{~mm})$. The gingival margin was located in cementum/dentin and the incisal margin in enamel. All cavosurface angles were finished with gingival margin trimmers. After the teeth were cleaned with pumice, cavity preparations were rinsed for $20 \mathrm{~s}$ with an air-water spray and gently air-dried for $30 \mathrm{~s}$. Materials used in the study are presented in Table 1.

Teeth $(n=35)$ were randomly divided into 5 groups and treated as follows:

Group 1 - Copalex (control): the varnish was applied in two thin layers, allowing the first layer to air dry for $30 \mathrm{~s}$ prior to applying the second layer.

Group 2 - Vitrebond: cavities were conditioned with Vitremer Primer, which remained in place for $20 \mathrm{~s}$, followed by photo curing for $20 \mathrm{~s}$. Powder and liquid of Vitrebond were mixed and a thin layer of the material was applied on cavity walls using a Centrix syringe.

Group 3 - RelyX ARC: the entire cavity was

Table 1. Materials used in the present study, and their respective batch number and manufacturer.

\begin{tabular}{lll}
\hline Material & Batch \# & Manufacturer \\
\hline Copalex (control) & $10 / 98$ & $\begin{array}{l}\text { Inodon, POA, } \\
\text { Porto Alegre, RS, } \\
\text { Brazil }\end{array}$ \\
& & 3 M ESPE \\
Vitrebond & 8265 R (ionomer) & St. Paul, MN, USA \\
& 734 (Vitremer Primer) & 3M ESPE \\
RelyX ARC & AAAA & St. Paul, MN, USA \\
& & Kuraray Co. \\
Clearfil Liner & 61156 & Osaka, Japan \\
Bond 2V & 010 BA (Bond B) & Kuraray Co. \\
Panavia 21 EX & 61218 & Osaka, Japan \\
& & SDI \\
GS-80 & 706472 & Victoria, Australia \\
& & \\
\hline
\end{tabular}

conditioned with $37 \%$ phosphoric acid. After washing and gently drying, dentin-bonding agent (Single Bond, 3M ESPE, St. Paul, MN, USA) was applied and photocured for $20 \mathrm{~s}$. RelyX ARC cement was mixed and a thin layer was applied in cavities using a brush.

Group 4 - Clearfil Liner Bond 2V: one drop of primer A and primer B were mixed and applied to the entire cavity, remaining in place for $20 \mathrm{~s}$. Since this material was used in dual-cured form, two drops (one of Bond $\mathrm{A}$ and one of Bond $\mathrm{B}$ ) were mixed and applied to the conditioned surfaces.

Group 5 - Panavia 21 EX: enamel was etched with phosphoric acid. After washing and drying, primer was applied to enamel and dentin. Panavia 21 EX cement was mixed and applied in a thin layer to the entire cavity using a brush.

Following the application of intermediate materials, amalgam was condensed into the cavities. Admixed capsuled amalgam GS-80 (Southern Dental Industries, Baywater, Victoria, Australia) was used to fill the cavities. An amalgamator (Ultramat 2, Southern Dental Industries) was set to 4,600 rpm for $8 \mathrm{~s}$. Amalgam was condensed in two horizontal increments using Ward and Hollemback condensers, before setting of the adhesive materials. Carving was performed using Hollemback 3S.

Specimens were then placed in distilled water for 7 days, when finishing and polishing of the restorations was performed. Specimens were submitted to thermal cycling for 500 times between $5^{\circ} \mathrm{C}$ and $55^{\circ} \mathrm{C}$, with a dwell time of $30 \mathrm{~s}$ at each temperature. After that, nail varnish was applied to the entire surface of the tooth except for the restorations and approximately 2 $\mathrm{mm}$ around them. The tooth apices were sealed with composite (Durafill VS, Heraus Kulzer, Dusseldorf, Germany) to avoid penetration of dye from the root canal.

The teeth were immersed in $0.5 \%$ methylene blue dye for $8 \mathrm{~h}$. The teeth were removed from the dye, and all the nail varnish was removed with a dentin curette. The specimens were then rinsed in tap water, dried and sectioned in a bucco-lingual plane with a water-cooled diamond saw. Two interfaces were created that were polished with $\mathrm{SiC}$ paper (\#250, 400 and 600 ), and examined in stereomicroscopy under $40 \mathrm{X}$ magnification by 2 calibrated examiners.

The degree of microleakage at both enamel and dentin margins was evaluated using a standard ranking 


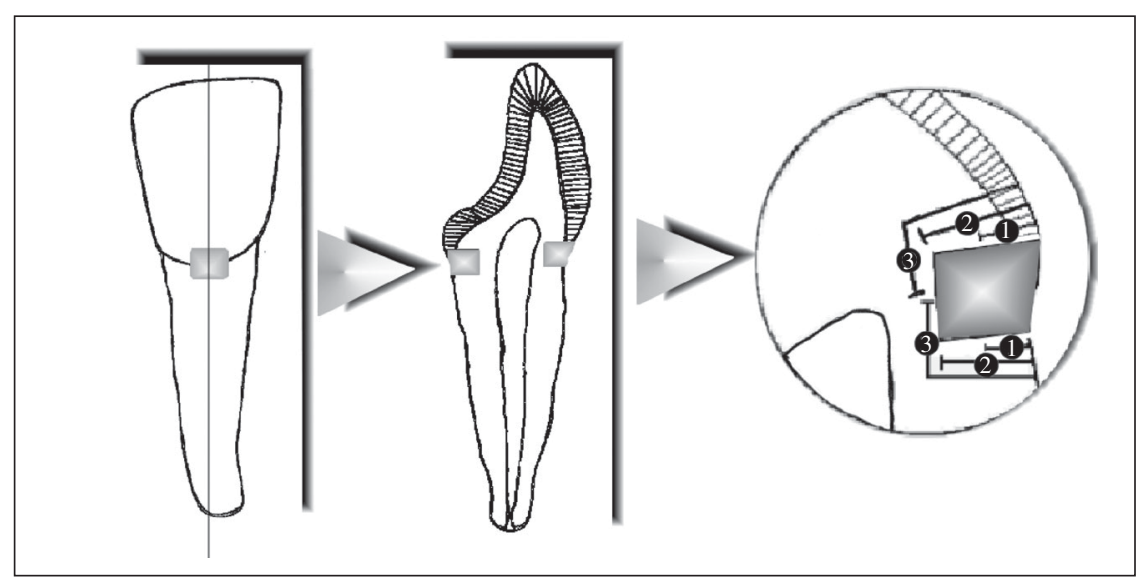

Table 2. Microleakage scores in enamel and cementum/dentin interfaces for the different groups (n=14/group).

\begin{tabular}{|c|c|c|c|c|c|c|c|c|}
\hline \multirow[t]{2}{*}{ Groups } & \multicolumn{4}{|c|}{ Enamel } & \multicolumn{4}{|c|}{ Cementum/dentin } \\
\hline & 0 & 1 & 2 & 3 & 0 & 1 & 2 & 3 \\
\hline Group 1 - Control & 5 & 0 & 0 & 9 & 1 & 0 & 0 & 13 \\
\hline Group 2 - Vitrebond & 14 & 0 & 0 & 0 & 14 & 0 & 0 & 0 \\
\hline Group 3 - RelyX ARC & 14 & 0 & 0 & 0 & 7 & 3 & 0 & 4 \\
\hline Group 4 - Clearfil Liner Bond 2V & 13 & 1 & 0 & 0 & 6 & 1 & 1 & 6 \\
\hline Group 5 - Panavia 21 EX & 13 & 1 & 0 & 0 & 4 & 0 & 0 & 9 \\
\hline
\end{tabular}

Scores: $0=$ No dye penetration; $1=$ dye penetration up to $1 / 3$ of cavity depth; $2=$ dye penetration up to $2 / 3$ of cavity depth; 3 = dye penetration up to the cavity floor.
Figure 1. Restoration diagrams and evaluation scores: $0=$ no dye penetration; $1=$ dye penetration up to $1 / 3$ of cavity depth; $2=$ dye penetration up to $2 / 3$ of cavity depth; 3 = dye penetration up to the cavity floor.

dentin were taken together (Kruskal-Wallis test), Vitrebond showed significantly less leakage $(p<0.05)$ than the other adhesive materials and the control group. The remaining adhesive materials exhibited similar results and demonstrated significantly less leakage $(\mathrm{p}<0.01)$ than the control group.

In enamel, all adhesive materials were similar and demonstrated statistically less leakage than the control group $(\mathrm{p}<0.01)$. In cementum/dentin, Vitrebond had less leakage than all other groups $(\mathrm{p}<0.01)$. RelyX ARC and Clearfil Liner Bond 2V had less leakage than the control group $(\mathrm{p}<0.01)$. Panavia $21 \mathrm{EX}$ was similar to Clearfil Liner Bond $2 \mathrm{~V}$ and the control, exhibiting greater dye leakage than Relyx ARC $(\mathrm{p}<0.05)$.

No specimen from the Vitrebond group exhibited dye penetration in either enamel or dentin/cementum margins.

\section{DISCUSSION}

One of the goals of an ideal restoration is to prevent microleakage. In vitro studies have been used to assess marginal leakage and compare restoration performances $(4,5,7)$. Different methods have been employed to evaluate microleakage around restorations and dye leakage is probably the most used method. The principal advantages of this technique are the low cost and ease of application (8). The disadvantages are the subjective evaluation of the results (8), the low molecular weight of the dye, which is smaller than that of bacteria, and the poor standardization of the method. 
Tests using dyes could detect leakage where bacteria could not penetrate.

Comparison of the results from different studies is critical, since there are no generally accepted standards for experimental parameters, such as type and concentration of the storage solution, time of storage, temperature during storage, type and duration of thermal cycling and/or mechanical cycling, and the scoring criteria (7). In addition, there is lack of correlation between in vitro and in vivo studies, since in vivo studies present some conditions that could hardly be reproduced in vitro. Nevertheless, results of in vivo studies are often less negative than in vitro studies. In vitro testing is essential for developmental purposes. Thus, in vitro results should be viewed as a theoretical level of maximum leakage, which may be expected in vivo (7).

In the present study, bovine teeth were used because of a decrease in tooth extraction making human teeth less available. Laboratory tests have demonstrated that bovine teeth are a suitable substitute for human teeth (9). The morphology of coronal dentin is similar between bovine and human teeth and enamel of bovine teeth is also similar to human substrate (9). Moreover, bovine teeth provide other advantages, such as similar age of the teeth and greater availability.

The results of the present study showed that adhesive materials reduced microleakage when compared with Copalex varnish liner. Similar findings have been reported when comparing Copalex varnish to resin-lined amalgam restorations (2-4).

Greater leakage was observed in cementum/dentin than in enamel margins. The difference between leakage in enamel and cementum/dentin margins could be attributed to the fact that cementum and dentin are less mineralized than enamel. Dentin presents tubules and is a moist tissue making adhesion less stable than in enamel. The greater permeability of dentin to dyes has been reported as a confusing factor in microleakage tests at the cementum/dentin margin (10). Moreover, the small size of methylene blue particles could give higher penetration in cementum/dentin margins (8). In enamel margins, there is more confidence in results because of the relative impermeability of this tissue (10).

Resin-modified glass ionomer as an intermediate material was effective in eliminating dye penetration in all specimens. Several in vitro studies have demonstrated the ability of glass ionomers to prevent leakage along the interface $(2,11)$. Micro-mechanical interlocking between amalgam and intermediate material has been considered responsible for adhesion in bonded amalgam restorations. It is important to point out that, in the present study, Vitrebond was applied following treatment of the cavity with the Vitremer primer, which is not a recommendation of the manufacturer. Such application was based on several studies in which previous treatment of tooth substrate increased adhesion of glass ionomer $(12,13)$. It has also been shown that resin-modified glass ionomer cement may produce hybridization with the dentin substrate. This ability was related to the primer used in the material, which contains HEMA and polyalkenoic acid, hydrophilic components that can increase bond strength to tooth structure. It is probable that adhesion of glass ionomer to metal may contribute to the improved performance of this technique in the present study (14).

Despite the absence of leakage in the Vitrebond group, one limitation of this material could be the higher solubility of the material in relation to other adhesive materials, which could reduce the effectiveness of the technique with aging. However, any procedure with the objective to offer resistance to oral microorganism attack will improve clinical performance of the restorations. Fluoride release of glass ionomer cements is an effective method for secondary caries prevention (15).

Microleakage in enamel was similar for both resin cements. However, Panavia 21 EX exhibited greater leakage at the cementum/dentin interface, similar to the control group. This could be related to the fact that the material contains only primers in the kit. The manufacturer indicates the application of the cement after primer conditioning. Once the cement is viscous, its penetration into the conditioned dentin surface could be reduced, impairing adhesion and facilitating microleakage. In enamel, etching with phosphoric acid and the higher mineral content of the tissue might allow better sealing.

The other cement used in this study (RelyX ARC) was used after total etching with $37 \%$ phosphoric acid and application of a hydrophilic dentin-bonding agent (Single Bond). This technique resulted in less leakage than Panavia 21 EX at the cementum/dentin margin. RelyX ARC is indicated for indirect restorations and bonded amalgam restorations and has demonstrated good adhesion to dentin and enamel and reduced microleakage. Also, the bonding agent employed 
has demonstrated ability to prevent leakage in Class $\mathrm{V}$ cavities (16).

Clearfil Liner Bond 2V showed intermediate results in relation to other adhesive materials in cementum/dentin, producing significantly less leakage than the control group. Clearfil Liner Bond $2 \mathrm{~V}$ is a selfetching, dentin-bonding agent that modifies the smear layer, allowing the penetration of the hydrophilic adhesive into the modified dentin. Using the previous version of this adhesive system, Bocangel et al. (17) found greater bond strength and less microleakage with Clearfil Liner Bond 2 compared to Scotchbond Multipurpose. The primers of Panavia 21 EX have similar action to the primers of Clearfil Liner Bond 2V. Perhaps, the combination of the two materials (Clearfil Liner Bond $2 \mathrm{~V}$ and Panavia) could improve the performance in bonded amalgam restorations. Several authors have suggested that the use of one dentin-bonding agent instead of a more viscous material could produce worse results (3). The application of the viscous intermediate material could promote a better mechanical interlocking with the amalgam.

Some evaluations of bonded amalgam restorations demonstrate the clinical performance of this technique. In a five-year study, Summit et al. (18) demonstrated that, for complex amalgam restorations, the bonding of amalgam appeared to be a viable alternative to mechanical retention of restorations. Bonded amalgam restorations can be used successfully in conventional preparations and possibly in nonretentive preparations as well, and can be expected to last at least five years (19).

Another advantage of bonded amalgam restorations is that they provide adequate retention to amalgam and cavity wall reinforcement. Studies have demonstrated cusp reinforcement by bonding of amalgam restorations (20).

Bonded amalgam was an effective technique, since all materials tested reduced microleakage compared to the control group. Also, one material (Vitrebond) provided total prevention of microleakage in all specimens.

\section{RESUMO}

O objetivo deste estudo foi avaliar a capacidade de diferentes materiais adesivos em previnir a microinfiltração em restaurações com amálgama aderido. Trinta e cinco incisivos bovinos foram selecionados. Foram preparadas cavidades padronizadas nas superfícies vestibular e lingual. A parede gengival estando localizada em cemento/dentina e a oclusal em esmalte. Os dentes $(n=35)$ foram divididos em 5 grupos, de acordo com o material empregado (um cimento de ionômero de vidro modificado por resina, dois cimentos resinosos, um sistema adesivo e um verniz cavitário como controle). Após serem restaurados, os dentes foram submetidos a termociclagem, sendo em seguida imersos em solução corante e então seccionados para permitir a avaliação da microinfiltração. A análise estatística não-paramétrica indicou que todos os materiais demonstraram menor infiltração do que o grupo controle $(p<0.01)$. Não foi detectada microinfiltração utilizando o cimento de ionômero de vidro modificado por resina, o qual mostrou menor infiltração do que os outros materiais adesivos $(\mathrm{p}<0.05)$. A infiltração em esmalte foi menor do que em cemento/dentina. Conclui-se que o amálgama aderido é uma técnica efetiva, uma vez que todos os materiais empregados preveniram a microinfiltração em esmalte e cemento/dentina, quando comparados ao grupo controle, com exceção do Panavia nas margens em cemento/dentina.

\section{REFERENCES}

1. Berry TG, Nicholson J, Troendle K. Almost two centuries with amalgam: Where are we today? J Am Dent Assoc 1994;125:392399.

2. De Morais PM, Rodrigues Junior AL, Pimenta LA. Quantitative microleakage evaluation around amalgam restorations with different treatments on cavity walls. Oper Dent 1999;24:217-222.

3. Meiers JC, Turner EW. Microleakage of dentin/amalgam alloy bonding agents: Results after 1 year. Oper Dent 1998;23:30-35.

4. Al-Jazairy YH, Louka AN. Effect of bonded amalgam restorations on microleakage. Oper Dent 1999;24:203-209.

5. Howdle MD, Fox K, Youngson CC. An in vitro study of coronal microleakage around bonded amalgam coronal-radicular cores in endodontically treated molar teeth. Quintessence Int 2002;33:2229.

6. Piva E, Martos J, Demarco FF. Microleakage in amalgam restorations: Influence of cavity cleansers solutions and anticariogenic agents. Oper Dent 2001;26:383-388.

7. Helvatjoglou-Antoniades M, Theodoridou-Pahini S, Papadogiannis Y, Karezis A. Microleakage of bonded amalgam restorations: Effect of thermal cycling. Oper Dent 2000;25:316-323.

8. Alani AH, Toh CG. Detection of microleakage around dental restorations: a review. Oper Dent 1997;22:173-185.

9. Schilke R, Lisson JA, Bauss O, Geurtsen W. Comparison of the number and diameter of dentinal tubules in human and bovine dentine by scanning electron microscopic investigation. Arch Oral Biol 2000;45:355-361.

10. Gale MS, Darvell BW. Dentine permeability and tracers tests. J Dent 1999;27:1-11.

11. Toledano M, Osorio E, Osorio R, Garcia-Godoy F. Microleakage of Class V resin-modified glass ionomer and compomer restorations. J Prosthet Dent 1999;81:610-615.

12. Buchalla W, Attin T, Hellwig E. Influence of dentin conditioning on bond strength of light-cured ionomer restorative materials and polyacid-modified composite resins. J Clin Dent 1996;7:81-84.

13. Nakanuma K, Hayakawa T, Tomita T, Yamazaki M. Effect of the application of dentin primers and a dentin bonding agent on the adhesion between the resin-modified glass-ionomer cement and dentin. Dent Mat 1998;14:281-286.

14. Fricker JP. A new self-curing resin-modified glass-ionomer ce- 
ment for the direct bonding of orthodontic brackets in vivo. Am J Orthod Dentofacial Orthop 1998;113:384-386.

15. Carvalho AS, Cury JA. Fluoride release from some dental materials in different solutions. Oper Dent 1999;24:14-19.

16. Moura FRR, Tomazzoni AJ, Ramos OLV, Demarco FF. Avaliação in vitro da infiltração marginal de 3 sistemas adesivos de frasco único. Rev Pos Grad FOUSP 2000;7:259-265.

17. Bocangel JS, Demarco FF, Palma RG, Turbino ML, Matson E. Influence of temporary filling with eugenol-containing cement on adhesion: Bond Strength, microleakage and SEM evaluations. Dent Mat J 1999;9:83-93.
18. Summitt JB, Burgess JO, Berry TG, Robbins JW, Osborne JW, Haveman $\mathrm{CW}$. The performance of bonded vs pin-retained complex amalgam restorations: a five-year clinical evaluation. J Am Dent Assoc 2001;132:923-931.

19. Mach Z, Regent J, Staninec M, Mrklas L, Setcos JC. The integrity of bonded amalgam restorations: a clinical evaluation after five years. J Am Dent Assoc 2002;133:460-467.

20. Dias de Souza GM, Pereira GD, Dias CT, Paulillo LA. Fracture resistance of premolars with bonded class II amalgams. Oper Dent 2002;27:349-353. 